\title{
Fiscal Policy in Europe: An Introduction
}

\author{
António Afonso ${ }^{1} \cdot$ Pedro Cerqueira ${ }^{2} \cdot$ Andreea Stoian $^{3}$
}

This special issue of Comparative Economic Studies includes seven papers from the International Network for Economic Research (INFER) Workshop on "New challenges for fiscal policy" organized by UECE-Research Unit on Complexity and Economics, at ISEG-Lisbon School of Economics and Management, Universidade de Lisboa, on 22 November 2019. ${ }^{1}$

The paper by Vítor Constâncio, who was the keynote speaker, is entitled "The Return of Fiscal Policy and the Euro Area Fiscal Rule" and addresses the return of fiscal policy to the frontline of economic thinking. Indeed, after monetary policy has emerged as the dominant policy, notably in the aftermath of the 2008 great financial crisis, such consensus started to change, and a new view has appeared, giving a more active role to fiscal policy.

The article entitled "Sustainable Debt Policy Rules and Growth in a Small Open Economy Model: Is a balanced government budget worthwhile?" written by Fabienne Lara Dascher uses a model of endogenous economic growth to analyze sustainable debt policy rules and economic growth by investigating the dynamics, the characteristics and stability of the steady state, and the welfare effects on the sustainable balanced growth path (SBGP) and along the transition path of different debt policies: the Balanced Government Budget (BGP) and the Permanent Public Deficits (PPD). The authors conclude that the PPD scenario yields a higher social

\footnotetext{
1 The program of the workshop can be seen in here: http://cefimo.ase.ro/workshop/2019/index.asp.
}

$\triangle$ António Afonso

aafonso@iseg.ulisboa.pt

1 Lisbon School of Economics and Management, Universidade de Lisboa, Lisbon, Portugal

2 Faculty of Economics, CeBER, University of Coimbra, Av Dias da Silva 165, 3004-512 Coimbra, Portugal

3 Department of Finance and CEFIMO, Faculty of Finance, Insurance, Banking and Stock Exchange, Bucharest University of Economic Studies, Bucharest, Romania 
welfare than the BGP, however, while the BGP generates always a stable SGBP, for certain model parameters the PPD generates cyclical growth rates.

The paper by Michael Buchner, "Fiscal Policy in an Age of Secular Stagnation," discusses relevant long-term trends in Europe in order to explain the currently low the interest rate paid on government debt and the output growth rate IRGD. The author builds three different scenarios, based on European Commission forecast, on long-term OECD estimations and on own calculations and panel regression analysis, show a negative IRGD for most EU member states for the next decade. Even though, the projections suggest an advantageously fiscal situation on aggregate, country-specific results vary widely. An exception is Italy which is likely to be confronted with interest rates larger than growth rates for the next 10 years. In addition, the financial crisis left many EU countries with a high debt burden. The negative IRGD can therefore substantially contribute to a reduction in the debt mountain. Countries with high debt levels should therefore continue their debt reduction path toward a sound fiscal position and increase efforts to implement structural reforms in order to boost long-term growth potential.

The paper by Philemon Kwame Opoku "The Short-Run and Long-Run Determinants of Household Saving: Evidence from OECD Economies," examines the relationship between interest rates and household saving rates for an uneven panel of 19 OECD countries during the period 1995-2018. The author finds that the income effect outweighs the substitution effect in the short run, and vice versa in the long run. In addition, inflation, household wealth through housing prices, unemployment rate, current taxes on income and wealth and general government debt have significant negative effects on household saving in the long run. In addition, financial development has a positive effect on household saving in the long run, while, rather as expected, taxes on income and wealth have a short-run negative impact on household saving.

The challenge posed by estimating potential output and the corresponding output gap for Italy is addressed in the article written by Tommaso Proietti, Marco Fioramanti and Cecilia Frale entitled: "A systemic approach to estimating the output gap for the Italian economy." According to the authors, besides the usual difficulties in measuring the output gap such as identifying the various sources of uncertainty, model specification and data availability, the Italian case poses new challenges due to the long-run decline in the underlying growth rate and the two consecutive recessions of considerable depth which increases the difficulty of disentangling the permanent dynamics from the transitory shocks. To cope with these challenges, the authors propose the use of a multi-model approach based on different economic theories but using the same econometric approach. The authors claim that, using this methodology, they can estimate a measure of uncertainty from the plurality of estimated output gap series. Moreover, they conclude that the estimates produced for Italy are characterized by low procyclicality, are consistent with the economic theory and that the estimates and forecasts of the output gap produced by other organizations tend to fall within the confidence interval calculated based on the models presented by them. Finally, the estimates can be combined to produce a consensus estimate using pooling weights that reflect the predictive ability with respect to inflation. 
Pedro Bação and Marta Simões bring to attention in their paper "Is the Welfare State Relevant for Economic Growth? Evidence for Portugal" an intensely debated issue in both academic and political circles regarding the welfare state and its role in stimulating the economic growth. The welfare state has grown significantly since the 1970s, being considered the main cause of high budget deficits and public debt accumulation, mainly in the advanced economies of Europe. This fact has generated much controversy. Economists have not yet reached a consensus on the positive or negative impact of the welfare state on economic growth, with studies providing evidence to support both effects. This article investigates how the welfare state in Portugal, considered among the most recent in Europe and which has faced many challenges since its establishment, impacts economic growth using a VAR model inspired by the Cobb-Douglas production function and a novel technique of specification-curve analysis (SCA) for the robustness. The analysis, also, takes into account the disaggregated impact of the various components of social spending. The results obtained are far from reconciling the existing divided opinions. The estimates indicate that the positive or negative effects vary depending on the method used, but that none of them is robust. However, the authors conclude that the research carried out does not support the increase in the social spending as a means of increasing production in Portugal in the long run.

Finally, the paper by Zoë Venter "The Interaction Between Monetary Policy and Financial Stability: Chile, Colombia, Japan, Portugal and the UK," assesses the relationship between monetary policy and financial stability using an SVAR model Monetary policy is represented by policy rates for the Emerging market economies and shadow rates for the advanced economies. The author reports that for the majority of cases monetary policy intervention may indeed contribute to financial stability. Moreover, the results show that the exchange rate appreciates in both the short run and the long run following a monetary policy shock for three of the five cases namely, the cases of Chile, Japan and Portugal while the currency depreciates for the cases of Colombia and the UK. The currency depreciation in the case of Colombia could be attributed to Colombia's reliance on commodity exports. The currency depreciation in the case of the UK is in line with the earlier literature.

Publisher's Note Springer Nature remains neutral with regard to jurisdictional claims in published maps and institutional affiliations. 